\title{
INTEGRATED DIMENSIONS OF SUSTAINABLE DEVELOPMENT
}

\section{Dr. BHAVESH H. BHARAD}

ABSTRACT: Sustainable development as defined by the Brundtland Commission 30 years ago is "development which meets the needs of current generations without compromising the ability of future generations to meet their own needs". ${ }^{1}$ Human rights are those basic rights and freedoms to which all humans are born with. When the basic needs and fundamental rights of individuals are not met, the ability to participate in social, economic, and environmental systems that promote sustainability is compromised. The Sustainable Development Goals (SDGs) was adopted at United Nations General Assembly through: "Transforming our World: the 2030 Agenda for Sustainable Development." ${ }^{2}$ The Sustainable Development Goals are the blueprint to achieve a better and more sustainable future for all. They address the global challenges faced like, those related to poverty, hunger, inequality, discrimination, climate action, quality education, health, clean water and sanitation, peace and justice etc. All these challenges are containing the human rights. The doctrine of these human rights without implementation of 17 Goals and 169 targets of the SDGs will not achieve their goal to 'leave no one behind'. These means the SDGs require all goals to be reached, for everyone-especially those who are far away from this. Although, that the term human right is not mentioned anywhere in all the 17 SDGs. So, my present paper focuses on a study how the contributions of sustainable development are integrated to human rights. Societal factors which influence human rights. Societal factors which influence human rights and global sustainability are often found deeply rooted and when these services not provided, it may pose a risk to citizens and their human rights, creating a conflict and instability, preventing them from participating fully in society, feeding an unjust cycle. Further paper also highlights how on other side people with full access to natural

\footnotetext{
${ }^{1}$ United Nations, Report of the World Commission on Environment and Development: Our Common Future, A/42/427, August 4, 1987.

${ }^{2}$ A/RES/70/1 - Transforming our world: the 2030 Agenda for Sustainable Development, 21 Oct 2015
} 
Towards Excellence: An Indexed, Refereed \& Peer Reviewed Journal of Higher Education / Dr. Bhavesh Bharad/ Page 274-288

resources, a clean environment, employment, education, and social services, are able to live peacefully and securing their lives ultimately contributing to sustainable communities.

Key Word: Sustainable Development, Human Rights, society.

\section{INTRODUCTION:}

This paper covers three main objectives:

First, I would like to emphasize on the relevancy of a systematic approach to human rights and development which was and has never been the most popular among politicians, jurists and scientists in the last half decade.

Second, I will identify the connection between the international human rights instruments and the concept of sustainable development and to narrate how this approach could be used in the context of human rights violations around the Globe.

Third, I desire to discuss some latest and related issues concerning the putting of the Linkage Human Rights - Sustainable Development Concept into practice - Especially the case of South Eastern Europe.

The narration of these topics will be an introductory and sketchy and not exhaustive - because of the broad subject. The main purpose is to put into discussion an interdisciplinary approach to the human rights violations and the possible solutions in the related field. I am of the opinion that the roots of the human rights violations are in the non-systematic approach to human rights and nonsustainable development.

"Poverty eradication without empowerment is unsustainable. Social integration without minority rights is unimaginable. Gender equality without women's rights is illusory. Full employment without workers' rights may be no more than a promise of sweatshops, exploitation and slavery. The logic of human rights in development is inescapable." -Mary Robinson, United Nations High Commissioner for Human Rights has the thought ever had come in your mind about the connection between human rights and sustainable development? If you think about the idea for an instant, you might come to realize like those other experts in the field have, that respect for and enforcement of human rights is a prerequisite for sustainable development. This proves that 
without acknowledging and acting to defend the rights of people, sustainable development is not possible.

Integrating the socio-cultural, economic and environmental components that are an integral part to a concept as encircling as 'sustainable development' is definitely not easy. "Sustainability" is really a simple concept of actions taken in the present to advance the human condition and the Earth system in which we live need to be lasting and benefit future generations. To achieve sustainability, decisions at all levels must consider the three integrated base pillars of sustainable development - socio-cultural, economic and environmental systems.

The simplest way to understand the linkages between human rights and sustainable development is to take any local and global issue which is presently considered as a challenge to the state of world affairs (e.g. any war or ethnic conflict, the HIV/AIDS crisis, oil spills in public waters) and analyze it covering the following concerns:

- Who is at advantage from this situation?

- What are the negative consequences of this issue to state or nation, and who is bearing the burden?

- Are the interests of the actors identified equally who are represented in the decision-making process?

- Will the consequences of this issue, and the actions taken to moderate it, have an impact on future generations of the nation?

These four questions demonstrate to us the reality picture that the capability to sustain basic standards of living in a healthy environment is not shared equally by all, as some people bear a unequal amount of the burden and do not always have their interests represented in the decisionmaking process.

\section{CONCEPT OF STOCKHOLM AND BEYOND:}

What is the root cause of talk about sustainable development? It actually comes through the historic UN Stockholm Conference on Environment and Development held in 1972 that the notion of sustainable development was born, and the linkage between environmental and development was finally brought together under one integrated concept. Again in 1992, the Rio Earth Summit brought the international community together to deal with global sustainable 
development challenges including various issues like climate change, health and the environment, biodiversity protection, and poverty alleviation.

However, thirty years after the first conference, major proportion of community are living in poverty and diseases such as HIV/AIDS which have paralyzed the social and economic fabric of particular countries, and disparity between the rich and the poor is increasing gradually over time. Furthermore, the environmental, the economic, and socio-cultural pillars of sustainable development were addressed separately.

In the era of research and technology, a new rights-based approach has been proposed. As we saw in Mary Robinson's revealing words, rights are central to every aspect of development, and a people-centered approach may be more successful at addressing the vicious cycle of poverty, environmental degradation, and the conflict.

The Proponents of the rights-based approach are supporting three main areas of concerns upon which to base the movement towards increased sustainability:

1. The right of clean and safe environment.

2. The open Access to information and People's Participation in decision-making

3. The right to promote and defend the protection of the environment and human rights

"It makes perfect sense to link human rights to sustainable development: the right to life cannot be realized without basic rights to safe water, air and land. A human rights approach allows the quality of life of all people to be a central part of decision-making."

- Adebowale et al. IIED Opinion paper - www.iied.org

Social security consists of policies and programmes designed to reduce poverty and vulnerability by promoting efficient labour markets, reducing people's exposure to risks, and enriching their capacity to manage economic and social risks, such as unemploymentation, exclusion, sickness, disability and old age (World Bank, 2001).

The United Nations 2030 Agenda recognizes social security systems as a key enabler for achieving Sustainable Development Goals (SDGs) (United Nations, 2015). Several SDGs and targets consider social protection as a vital condition for their successful implementation. Each SDG and target adheres to either one or more provisions of International Human Rights treaties. 
In this context, the present paper highlights the relevance of harnessing the SDGs-human rights considered as a roadmap to implement social protection policies and practices towards realizing the 2030 Agenda.

In 1986, Member States of the United Nations proclaimed the 'Declaration on the Right to Development.' The Declaration acknowledged that everyone is 'entitled to participate in, contribute to, and enjoy economic, social, cultural and political development, in which all human rights and fundamental freedoms can be fully realized.' The Declaration also states that 'States have the duty to cooperate with each other in ensuring development and eliminating hurdles to development.'

The right to development is not all about charity, but enablement and empowerment. The Declaration covers various aspects such as identifying obstacles to development, empowering individuals and a person, call for an enabling environment and good governance at both national and international levels, and enhances accountability of duty bearers such as governments, donors and recipients, international organizations, transnational corporations, and civil society.

The year 2016 completed Declaration's 30th anniversary but still today many children, women and men - the very subjects of development - still survive in dire need of the fulfillment of their right based needs to a life of dignity, freedom and equal opportunity. Widening poverty gaps, food shortages, climate change, global financial crises, corruption and the misappropriation of public funds, armed conflicts, rising unemployment, and other hard challenges represent a collective failure to understand the right to development. And that failure in turn, directly impacts the realization of a wide range of civil, political, economic, social and cultural rights.

The Human Rights Council concluded its 37th regular session in March 2018 by addressing a wide range of human rights issues and heard 95 reports of human rights experts addressing 35 thematic and 50 country-specific situations. Among the 42 adopted resolutions, the Council accepted two complementary texts aimed at mainstreaming human rights in the implementation of the 2030 Agenda for Sustainable Development.

The first complementary text titled, 'Promotion and Protection of Human Rights and the implementation of the 2030 Agenda for Sustainable Development' (A/HRC/RES/37/24), was 
introduced by a core drafting committee of 41 States led by Brazil, Denmark, Canada and Chile and supported by 29 others. This resolution establishes a strong linkage between the 2030 Agenda and International Human Rights obligations of States. First, it considers that the implementation of SDGs must be "consistent with a state's obligations under international human rights law." In other words, the execution of development plans should not undermine human rights obligations or lead to discrimination or marginalization of vulnerable groups. The resolution concludes that the promotion and protection of human rights and the execution of the 2030 Agenda are "interrelated and mutually reinforcing." Indeed, on contrary, the 2030 Agenda is clearly "depicted in the Universal Declaration of Human Rights and international human rights treaties" (paras. 10 and 19). Moreover as stated in the Preamble, the SDGs "seek to realize the human rights of all". In addition to this, the SDGs provide a matrix of targets and indicators essential for measuring progressive realization of human rights.

Second, the resolution has noted the important contribution that international human rights mechanisms, including the Human Rights Council itself, treaty bodies and special procedures, already make in promoting the implementation of the SDGs. For instance, in the past four sessions following the adoption of the 2030 Agenda, the Human Rights Council has adopted various seven resolutions dedicated to human rights for mainstreaming in the implementation of the SDGs. Supplementary examples can be found in concluding observations of the treaty bodies (see, for instance, 2017 CEDAW concluding observations for Thailand, 2017 CMW concluding observations for Jamaica or 2017 CPRD concluding observations for Jordan). Other instances of contributions to advancing and implementing the SDGs can be observed in the work of the UN Special Procedures. The SDGs were the focal point of several mandate holders that presented reports in June 2017, at the 24th annual meeting of special rapporteurs and representatives, independent experts and working groups of the Council's special procedures (A/HRC/37/37).

Reports on people of African descent, on the role of equity and inclusion in strengthening the right to education based on contemporary forms of slavery and recommendations on the business and human rights dimension of sustainable development highlighted interlinkages and integration with the Goals Special procedures have addressed the implementation of the SDGs in their thematic reports, issued open letters, participated in gatherings, and raised matters related to the SDGs during country visits (see Para. 40 of the report A/HRC/37/37). Moreover, establishing the connection between human rights and the SDGs is one of the existing strategic priorities of the special procedures mandate holders (see paras. 63 and 69 of the report A/HRC/37/37). This 
priority is in line with the existing trend relating to strengthening cooperation within the United Nations and enhancing cohesion among mandate holders. SDGs provide an excellent framework for such assistance. In pursuing this priority, the mandate holders discussed relation and integration between human rights, SDGs and resource mobilization, in particular, the benefits of compiling recommendations, concluding remarks, and general comments by special procedures and treaty bodies relevant to the implementation of SDGs (see report by the International Bar Association's Human Rights Institute).

Finally, the resolution suggests that relying on the standing agenda item 10 of the Human Rights Council to effectively support the States in implementing SDGs in a way that would be fully consistent with their international human rights obligations. This long-established machinery of technical cooperation and capacity building includes a set of targeted measures aimed at aiding States to stay faithful to their human rights obligations, particularly in times of armed conflicts or other crises.

In order to achieve closer coordination between human rights and the 2030 Agenda, the Resolution mandates the Office of the High Commissioner for Human Rights (OHCHR) to arrange twice a one-day intercessional meeting for dialogue and cooperation between States, the UN human rights mechanisms and other stakeholders. Importantly for a better coordination within the UN system, such gatherings ought to interact substantively with the annual themes of the UN High-level Political Forum on Sustainable Development (HLPF) and should provide a summary report of the discussions so that the HLPF can use in its activities. The first resolution, therefore, has a practical focus and an agreed method of work.

The subsequent resolution titled, 'The need for an integrated approach to the implementation of the 2030 Agenda for Sustainable Development for the full realization of human rights, focusing holistically on the means of implementation' (A/HRC/RES/37/25), was hosted by South Africa and supported by 22 States. This Resolution has an obvious focus on the right to development, despite the lack of universal recognition of this human right. The resolution recalls the UNGA Declaration on the Right to Development, which considers that states have "the right and the duty" to introduce development policies aimed at fair distribution of the benefits resulting there from.

In a similar way to the first resolution, this complementary text establishes a strong connection between development goals and human rights leading a special focus on gender equality and the empowerment of women and Children. In this context, and also recalling that all goals and 
targets of the Agenda 2030 are universal, indivisible and interlinked, the Resolution clearly reaffirms that the 2030 Agenda has grounded in and seeks to realize human rights and fundamental freedoms for all. This explanation has been accepted by various stakeholders (see, for example, OHCHR and the Danish Institute for Human Rights). At an end for the practical follow-up, the Resolution invites the President of the Economic and Social Council (ECOSOC) to brief the Human Rights Council on an annual basis on the work of the HLPF and on the implementation of the 2030 Agenda in an integrated and holistic manner.

Taking together, the two resolutions strongly contribute to strengthening of the normative framework that establishes integration and connection between human rights and development, in particular, to the 2030 Agenda. Apart from these two resolutions specially framed aiming mainstreaming human rights in the implementation of SDGs, a large majority of thematic resolutions adopted at the 37th session of the Human Rights Council, just as in past years, contain a reference to the SDGs and aim at implementing a specific goal or target. For example, the resolution on promoting human rights and the SDGs through transparent, accountable and efficient public services delivery and utilities (37/7) refers to Goal 16, which "encourages Member States to promote peaceful and inclusive societies for sustainable development, provide easy access to justice for all and build effective, accountable and inclusive institutions at every level". Resolution on the right to food (37/10) refers to Goal 2 and subsequent food and nutrition-related targets on "ending hunger, achieving food security and improved nutrition and promoting sustainable agriculture and on ending poverty in all the forms worldwide". The resolution on adequate housing as a part of the right to an adequate standard of living (37/4) specifically depicts Goals 1 and 11 and highlights the relevance of making cities and human settlements inclusive, safe, resilient and sustainable. It mandates and compels the States to implement the 2030 Agenda for Sustainable Development, including target 11.1 on access to adequate, safe and affordable housing and basic services for all.

Such interpenetration is a tangible sign that implementation of the SDGs has been accorded at a very high place on the existing political agenda, and the states being the drafters and sponsors of resolutions, take their obligations relating to human rights and development seriously.

The Sustainable Development was considered as Strategic Function of the International Human Rights Instruments during 1987 under an act of the World Commission on Natural Environment at the UN. A group of experts, lead by Mrs. Brundland, prepared a report which for the first time 
introduced the term "Sustainable Development". This report has rendered an infinite number of discussions but at the end of the day, the international community got united in its understanding that the foundation of the new concept for analyzing and regulating social processes is the systematic approach and this understanding acquired the political acknowledgement from approximately around 170 governments during the Rio meeting of 1992. The scientific and political elite of the World has understood, that no problem can find its solution until the exact and full evaluation of all related factors is comprehended. For instance, Environmental pollution is a phenomenon directly connected to relevant economic and political problems. The solving of one of the most acute and sensitive social problems - unemployment - is impossible without searching for and finding the connection between labor and education, between labor and political participation, etc. The geneses of the wars in Former Yugoslavia are not only ethnical, but also economic too.

The concept of "sustainable development" considers constructive ideas for combating against a number of negative features, typical of contemporary society. From an intellectual point of view the concept becomes a source of a new type of system of values and renders support to the elaboration of the mechanisms for regulating processes in the fields of economy, social and environmental spheres. It is not a new philosophy but rather a system of principles, consolidating the most valuable elements of traditional ideologies by adopting the systematic approach to social development. Its most important characteristic, however, is that is surmounts the one-sided view of development, typical of the 20 century i.e. economic growth and material prosperity at any cost.

On the basis of UN documents, national development strategies and publications, the following basic principles can be formulated rendering leading ideas on development, intellectual modes of necessary behavior of all participants in the political process within the context of sustainable development, under the provision that thus presented, they cannot claim to be a well-organized system of principles but are rather major points of orientation and exposure for the public policy on national, regional and global level:

- the economy should be of such service to man and economic growth should be directed at the healthy and complete socially secured life of each individual in harmony with the nature; 
- there should be maximum participation of each member of society in the process of decision-making because the leading principle of the sustainable society is "equal opportunities for all”;

- a well-preserved equilibrium between economic, technological and social development and clean environment should be there;

- biological stability of the natural environment, preservation of the biological diversity and the biosphere be made mandatory;

- rational and environmentally adequate reasonable exploitation of resources;

- denial of production processes, which are life-threatening and unhealthy for humans and the environment;

- regulatory frame work of demographic processes in accordance with the fundamental laws of nature and the given specific conditions in compliance to it;

- eradication of poverty, unemployment and the unequal distribution of material wealth;

- Importance to the process of democratization and enhancing the role of the structures of civil society;

- ensuring sexual, racial, ethnical and gender equality between the different social groups;

- eradicating all forms of violence and discrimination and violation of human dignity;

- development and enhancement of regional cooperation and global partnership in every sphere of social life;

- easy and free access to information and the achievements of science and the arts;

- development of innovative principles of governance and a new legislative basis on a national, regional and global level directed at the establishing of cooperation and avoiding all possible dangers, standing before contemporary society and the natural environment;

- modifying the educational system to present needs, the spiritual sphere and the system of values in tone with contemporary realities;

- every nation will have the sovereign right to develop national programs and expose its own resources and strategies under the condition that does not violate internationally accepted norms and the biosphere;

- national governments are the sole guarantors of the economic development, social justice, the protection of the environment and they carry the burden of accountability for any and all violations of the norms, accepted by the international community; 
- with holding all pretensions for new territories.

The constructive idea behind the formulating these intellectual principles is to merge the values supporting traditional ideologies and make them serve as sources of orientation for national governments and international institutions when formulating their strategy and policies. Aiming at the greater generalization, the principles of "sustainable development" may be arranged in a system of four targeted groups:

- dignified treatment on need base of each member of society;

- enriching political and juridical accountability of governments and international institutions

- influential and effective civil society;

- human - oriented and equality based economic growth;

- Healthy environment and control of dangerous production processes.

This systematization and synchronization of the principles of sustainable development exemplifies, that they are inter-related and that to a considerable extent, coincide with the traditional "systematization" of human rights or the so-called "three generations of human rights": civil and political rights; social and economic rights; third generation rights. It now becomes apparent, that the innovation in the concept of sustainable development is not so much in the content of its principles but in the systematic approach, demanded for their effective implementation.

The systematic approach can also be traced in the Universal declaration of the UN and the international instruments for the protection of the rights that appear as a consequence. Here we can observe the connection between sustainable development and human rights too. The values and principles which ensures for the concept of sustainable development, play the role of political principles while the norms for the protection of human rights frames the legal principles, within which the state power is to be applied. Both the principles are directed towards achieving sustainable development especially overcoming poverty and inequality between the state of development of different countries and regions; controlling the process of environmental deterioration and guaranteeing individual and social security for each member of society.

Defining the new concept of development, a lot of scientists accept as a starting point the Article 25 of the Universal Declaration of Human Rights which was adopted in Paris on December 1948. 
Everyone has the right to a standard of living that is adequate to ensure the health and wellbeing of himself and his family, especially as regards food, clothing, shelter and medical care, as well as social services; he has the right to protection against unemployment, sickness, disability, bereavement, old age or other cases of the loss of livelihood because of circumstances beyond his control...

It means that the looking for a new type of understanding of "development" is not a matter of creating a new theory or ideology but is the challenge is to make more effective the mechanisms, which can overcome the "shocking gulf" between the high-sounding words of Article 25 UDHR and the "scandalous" reality of underdevelopment and poverty in the World. The challenge is to "to take human rights seriously" and to improve the instruments for their protection so that they to make the functioning of the political systems more effective - to lead the society toward development.

\section{THE CASE OF SOUTH-EAST EUROPE:}

Incorporating the third part of my article I would like to flash light on the case of South-East Europe. The case as such is: in spite the well development of mechanisms and instruments for human rights protection on European level in the last ten years have been witnessed but still we were and continue to be witnesses of "gross" human rights violations - especially in South Eastern Europe - because of a non-utilizing of the potential of the linkage between human rights and sustainable development concept.

Mainly three factors are responsible in determining the situation in Europe after the break-down of "the communist systems". It required and requires a systematic approach through which the Linkage between Human Rights - Sustainable Development Concept into practice - the globalization, European Union Enlargement, geopolitical positions of the states can be enhanced.

\section{CONCLUSION:}

Two broad concepts of Human rights and social protection have integrated as two key elements after 2015 under the umbrella of development agenda. The 2030 Agenda has been depicted and 
considered in the Universal Declaration of Human Rights and other international human rights treaties. Social protection is a human right has been considered and enshrined in the UDHR and several other international human rights treaties. Each SDG and target corresponds and complies with either one or more provisions of international several human rights treaties.

These SDGs - human rights anchorage enables the adoption of a rights-based approach to implement social protection policies and programmes towards advancing the achievement of the established SDGs. In this context, a global meet on the mutually reinforcing roles of human rights, social protection and SDGs would be a timely step in the direction of realizing the 2030 Agenda.

\section{REFERENCES:}

1. International Labour Organization, ILO (1944). Declaration of Philadelphia, 1944. http://blue.lim.ilo.org/cariblex/pdfs/ILO_dec_philadelphia.pdf

2. International Labour Organization, ILO (2012). Social Protection Floors Recommendation \# 202, 2012 .

http://www.ilo.org/dyn/normlex/en/f?p=NORMLEXPUB:12100:0::NO::P12100_ILO_COD E:R202

3. The Danish Institute for Human Rights (2016). The Human Rights Guide to the Sustainable Development Goals, http://sdg.humanrights.dk/en.

4. United Nations (2015). General Assembly, Transforming Our World: the 2030 Agenda for Sustainable Development, 21 October 2015, A/RES/70/1.

Accessible: http://www.refworld.org/docid/57b6e3e44.html

5. United Nations (1948). General Assembly, Universal Declaration of Human Rights, 10 December 1948, 217 A (III).

http://www.refworld.org/docid/3ae6b3712c.html

6. United Nations (1966). General Assembly, International Covenant on Economic, Social and Cultural Rights, 16 December 1966, United Nations, Treaty Series, vol. 993 3-4.

http://www.refworld.org/docid/3ae6b36c0.html 
Towards Excellence: An Indexed, Refereed \& Peer Reviewed Journal of Higher Education / Dr. Bhavesh Bharad/ Page 274-288

7. United Nations General Assembly, International Convention on the Elimination of All Forms of Racial Discrimination, 21 December 1965, United Nations, Treaty Series, vol. 660 194-195 (1965).

http://www.refworld.org/docid/3ae6b3940.html

8. United Nations (1979). General Assembly, Convention on the Elimination of All Forms of Discrimination Against Women, 18 December 1979, United Nations, Treaty Series, vol. 1249 13-14.

http://www.refworld.org/docid/3ae6b3970.html

9. United Nations (1989). General Assembly, Convention on the Rights of the Child, 20 November 1989, United Nations, Treaty Series, vol. 1577 3-4.

http://www.refworld.org/docid/3ae6b38f0.html

10. United Nations, HRBA Portal. The Human Rights Based Approach to Development Cooperation: Towards a Common Understanding Among UN Agencies.(2008) http://hrbaportal.org/the-human-rights-based-approach-to-development-cooperationtowards-a-common-understanding-among-un-agencies

11. United Nations, HRBA Portal. What is a human rights-based approach? (2008). http://hrbaportal.org/faq/what-is-a-human-rights-based-approach

12. World Bank (2001). Social Protection Sector Strategy Paper: From Safety Net to Springboard. Washington DC, USA.

13. INGA T. WINKLER \& CARMEL WILLIAMS. The Sustainable Development Goals and human rights: a critical early review. The International Journal of Human Rights 21:8 10231028 (2017).

14. JAYNE CAUDWELL \& DARRAGH MCGEE. From promotion to protection: human rights and events, leisure and sport. Leisure Studies 37:1, pages 1-10 (2018).

15. The Human Rights Council and the SDGs: an overview.

16. Rights and the 2030 Agenda for Sustainable Development.

17. Draft resolution A/HRC/37/L.37 on 'Promotion and protection of human rights and the implementation of the 2030 Agenda for Sustainable Development', adopted without a vote at HRC37, March 2018.

18. Human rights and the 2030 Agenda for Sustainable Development, delivered by Chile on behalf of Denmark, Ecuador, Luxembourg, Portugal, Rwanda, and Uruguay, announced a 
new initiative to leverage the mutually-reinforcing and mutually-interdependent nature of human rights and the Sustainable Development Goals (SDGs), March 2017.

19. HRC statement of President of the Republic of Chile, H.E. Michelle Bachelet Jeria, March 2017.

20. The road to dignity by 2030: ending poverty, transforming all lives and protecting the planet, Synthesis report of the Secretary-General on the post-2015 sustainable development agenda (A/69/700), December 2014.

\section{Dr. BHAVESH H. BHARAD \\ Assistant Professor, University School of Law, Gujarat University, Ahmedabad dr.bharad@gmail.com}

